\title{
Serosurveillance of Brucella antibody in food animals and role of slaughterhouse workers in spread of Brucella infection in Southeast Nigeria
}

\author{
Samuel Okezie Ekere ${ }^{1}$, Emmanuel Okechukwu Njoga², Joseph Ikechukwu Onunkwo² and Ugochinyere Juliet Njoga ${ }^{1}$
}

1. Department of Veterinary Obstetrics and Reproductive Diseases, Faculty of Veterinary Medicine, University of Nigeria, Nsukka, Enugu State, Nigeria; 2. Department of Veterinary Public Health and Preventive Medicine, Faculty of Veterinary Medicine, University of Nigeria, Nsukka, Enugu State, Nigeria.

Corresponding author: Emmanuel Okechukwu Njoga, e-mail: njoga.emmanuel@unn.edu.ng

Co-authors: SOE: samuel.ekere@unn.edu.ng, JIO: joseph.onunkwo@unn.edu.ng, UJN: ugochinyere.njoga@unn.edu.ng Received: 06-03-2018, Accepted: 19-07-2018, Published online: 27-08-2018

doi: 10.14202/vetworld.2018.1171-1178 How to cite this article: Ekere SO, Njoga EO, Onunkwo JI, Njoga UJ (2018) Serosurveillance of Brucella antibody in food animals and role of slaughterhouse workers in spread of Brucella infection in Southeast Nigeria, Veterinary World, 11(8): 1171-1178.

\begin{abstract}
Aim: The study was carried out to determine the seroprevalence of Brucella antibody in slaughter cattle and goats; and the role of slaughterhouse workers (SHWs) in spread of Brucella infection during slaughterhouse operations in Enugu State, Southeast Nigeria.

Materials and Methods: Rose Bengal plate test was used to screen for Brucella antibody in 484 cattle and 340 goats slaughtered for human consumption in the state. Structured and pretested questionnaire was used to elicit information from randomly selected SHWs, on socioeconomic characteristics, awareness of brucellosis and involvement in practices that aid dissemination of Brucella infection during slaughterhouse operations.

Results: Suspected seroprevalence of $2.5 \%$ and $4.1 \%$ were recorded for Brucella antibody in cattle and goats respectively. There was poor awareness of brucellosis (32.1\%) among the workers surveyed. Slaughterhouse practices that aid acquisition or spread of Brucella infection and percentage of SHWs engaged in the practices are: non-use of personal protective clothing during slaughterhouse operations $(70.8 \%)$, discharge of eviscerated fetuses or pregnant uterine contents by open-air dump method of refuse disposal $(64.9 \%)$ and illegal sell of eviscerated fetuses or gravid uterine contents for human consumption $(59.9 \%)$ or preparation of $\operatorname{dog}$ food $(71.5 \%)$.

Conclusion: The 4.1\% suspected seroprevalence of Brucella antibodies in goats represents $128 \%$ increase from $1.8 \%$ seroprevalence earlier reported in the same species and study area in 2009. Significant amounts of Brucella antibody was detected in the food animals screened. Slaughterhouse workers played significant roles in spread of Brucella infection by their involvement in risk practices and behaviours that facilitate pathogen transmission. Therefore, massive awareness campaign and coordinated brucellosis control program in Enugu State are imperative to forestall the zoonotic and economic consequences associated with brucellosis.
\end{abstract}

Keywords: Brucella antibody, brucellosis, cattle, goats, slaughterhouse workers.

\section{Introduction}

Livestock production is a major employer of labor in most developing economies. In agrarian communities in Sub-Saharan Africa, livestock production is widely practiced due to the availability of abundant lush pasture at no cost to the farmers; and also as precautionary measure against crop failure. In most traditional African settings, ownership of livestock is a measure of economic and social status; as well as a form of cash reserve for financing immediate family needs. However, the endemicity of microbial pathogens, such as Brucella in tropical climatic regions, has been a major drawback to livestock farming and the

Copyright: Ekere, et al. Open Access. This article is distributed under the terms of the Creative Commons Attribution 4.0 International License (http://creativecommons.org/licenses/by/4.0/), which permits unrestricted use, distribution, and reproduction in any medium, provided you give appropriate credit to the original author(s) and the source, provide a link to the Creative Commons license, and indicate if changes were made. The Creative Commons Public Domain Dedication waiver (http://creativecommons.org/ publicdomain/zero/1.0/) applies to the data made available in this article, unless otherwise stated. profitability of the farming business in these parts of the world.

Brucellosis is a dreaded bacterial zoonosis with great public health and food safety importance. Brucella pathogens in edible animal tissues are transmissible to humans through the food chain and human food habits, once formed are very difficult to change. The disease has a cosmopolitan distribution, and affects economically important domestic livestock as well as a wide range of other terrestrial and aquatic animals [1,2]. Although more than eight different Brucella species have been described, Brucella abortus, Brucella melitensis and Brucella suis are responsible for most of the disease burden globally [3]; preferentially infecting cattle, small ruminants and swine respectively. Despite their distinct host preferences, Brucella agents cause brucellosis of varying severity in most terrestrial animals and humans [4]; especially in mixed husbandry systems or at the animal-human interfaces [3].

The economic importance of brucellosis in livestock production finds expression in reduced 
productivity in livestock due to infertility problems caused by the disease agents [5], high costs of treatment, prevention or control measures against the disease [6], and heavy financial losses occasioned by restrictions in local and international trades in infected animals or their products [7]. Brisibe et al. [8] estimated an annual loss of US $\$ 3.2$ million to brucellosis in only two States in Nigeria while Bamaiyi et al. [9] reported a loss of US\$2.6 million per annum in Malaysia due to the disease.

Brucellosis occurs in most food-producing animals and may be acquired venerally, congenitally, through inhalation of aerosolized Brucella organisms in overcrowded or overstocked settings [3-6]. The disease in animal may also spread by contact with or ingestion of fluids or tissues from infected animals $[2,10]$. B. melitensis is by far the most virulent Brucella organism and the genus with the highest zoonotic potential [11]. The organism has a very low infective dose of just about 10 organisms [12, 13], capable of penetrating a host through skin abrasion [14] and causing brucellosis in a broad host range (goats, sheep, cattle and humans) under natural conditions $[6,14]$. Infertility problems such as middle or late-term abortion, birth of weak/unthrifty neonates and repeat breeder syndrome are major clinical manifestations of brucellosis in food animals leading to mass or frequent culling of infected animals for slaughter.

In most developing countries in the tropics, food animals are mostly slaughtered at homes, slaughterhouses/slabs or at clandestine locations due to a limited number of standard abattoirs. At these slaughter points, factors such as tropical climatic conditions, unsafe hygienic practices among slaughterhouse workers and inadequate knowledge of brucellosis as well as the dynamics of the disease spread tend to facilitate Brucella transmission from food animals to humans. These factors seem to also favor the persistence of Brucella pathogens in the environment and its onward transmission to animals grazing or scavenging around the slaughter points and meat processing environment. Food animals and pets are reservoirs of human brucellosis and high brucellosis burden in animals is a major determinant of the human disease $[15,16]$. Brucellosis outbreaks in livestock populations are usually triggered by poor farm management practices which permit the use of infected animals for breeding or defective biosecurity programs in farms where "farm to fork" concept of food safety is largely ignored.

The incidence of human brucellosis is about 500,000 cases per year worldwide $[14,17]$ and is usually caused by $B$. abortus, B. melitensis, B. suis or $B$. canis [13]. Although $B$. ovis is the principal agent of ovine brucellosis, the agent has not been associated with any case of human brucellosis [13]. B. melitensis and B. abortus are the most important and most frequent causes of human brucellosis often implicated in most cases of the human disease worldwide $[12,18]$. Human brucellosis is a disease of variable manifestations, with severe debilitating complications that warrant prolonged therapy with antibiotic combinations. Although there is no vaccine against human brucellosis, human-to-human transmission of the disease has not been reported [2,14]. Effective control of human brucellosis transmission via the food chain depends on strict compliance to food safety measures such as milk pasteurization and proper cooking of animal product before consumption.

Brucellosis poses a serious public health threat to animal health workers, livestock farmers and slaughterhouse workers (SHWs), who are particularly at risk of the disease due to their occupational exposure. Animals are important source of Brucella infection to humans and the risk of human exposure to brucellosis depends on the disease burden in animals [19]. Brucellosis in humans may be acquired through consumption of infected raw or undercooked animal products, as well as by wound contamination with infected fluids or tissue [14]. Factors that may affect human exposure to brucellosis, particularly among the occupationally exposed individuals, include non-use of personal protective clothing (PPC) during routine operations and inadequate knowledge of the disease and its transmission dynamics [20].

Although brucellosis has been controlled in most industrialized nations, the disease has become a neglected zoonosis in some tropical or developing countries due to lack of sustainability in the disease prevention and control programs $[10,12]$. Consequently, brucellosis has continued to ravage these parts of the world, where livestock farming is coincidentally a major employer of labor and source of livelihood [11,14].

Establishment of adequate control programs against brucellosis in a population depends on the presumptive diagnosis of the infection. Diagnosis of brucellosis by culture and isolation of Brucella organisms from clinical samples is the preferred method of diagnosis, but this method is laborious, time-consuming, risky and its outcome depends on the competence of the laboratory personnel [21]. Serological tests offer best alternatives to culture and isolation method of diagnosis since the tests are easy to perform, less risky and provide result within a short period. Rose Bengal plate test (RBPT) has been recommended for brucellosis screening due to its high sensitivity and relatively low cost, especially in developing countries where the disease burden may be high and the facilities for modern methods of diagnosis unavailable [2].

Despite many reports on the occurrence of Brucella antibody in cattle $[16,19,20,22,23]$ and goats $[19,22,24]$ in other parts of Nigeria; data on the seroprevalence of Brucella antibody in food animals in the study area are dated, few and far between. Information on the role of SHWs on slaughterhouse practices that facilitate dissemination of Brucella infections during slaughterhouse operations in Enugu State is lacking.

The study was therefore carried out to determine the seroprevalence of Brucella antibody in slaughter 
cattle and goats; and also the role of SHWs in spread of Brucella infection, during routine slaughterhouse operations in Enugu State.

\section{Materials and Methods}

\section{Ethical approval}

Ethical clearance for care and use of animals is not applicable to this study since blood samples used were collected from slaughtered animals at the abattoir.

\section{Informed consents}

Oral consent to participate in the study was sought and obtained from all human subjects included in the study. Consequently, 137 respondents were randomly selected and interviewed from those who consented to participate in the survey.

\section{Study area}

This study was carried out in Enugu State, Southeast Nigeria. The state has map coordinates of $6^{0} 30^{\prime}$ North and $7^{0} 30^{\prime}$ East and a population of about 5 million people [25]. Enugu State has a tropical climate characterized by wet (April to October) and dry (November to March) seasons. The state is typically an agrarian society dominated by crop farmers and civil servants. However, small and medium scale food animal production, as additional source of income or precautionary measure against crop failure is widely practiced.

\section{Questionnaire survey}

Structured and pretested questionnaire (closed ended) was used to extract information on educational level, awareness of brucellosis, use of PPC during routine slaughterhouse operations and method of disposal of slaughterhouse waste from 137 randomly selected SHWs. The questionnaire was administered in the form of an interview, in indigenous language, to respondents who are limited in their ability to read or write English language. Thereafter, the questionnaires were retrieved and the responses collated, analyzed and presented in tables.

\section{Sample collection}

Research visits to three major slaughterhouses (Ikpa, Akwata and $9^{\text {th }}$ mile) in Enugu State for blood sample collection were made weekly for 6 months; consisting of 3 months of dry season (January-March) and another 3 months of rainy season (June-August). The simple random sampling method was used to select animals to be sampled. The sex and breed of each selected animal were determined by visual examination while age was estimated using history (if available) and teeth eruption and wear method as described by Pace and Wakeman [26]. Cattle and goats that are $<1$ year old do not usually present signs of brucellosis or are slaughter for food, and were therefore excluded from the study. About 5-10 mL of blood was aseptically collected from each selected animal during bleeding. The blood samples were kept in a slant position for about $3 \mathrm{~h}$ and sera samples formed were harvested and stored at $-20^{\circ} \mathrm{C}$ until the brucellosis screening test was performed.

\section{Sample screening}

The RBPT as described by Amin et al. [27] was performed by mixing equal volumes $(30 \mu \mathrm{l})$ of stained Brucella antigen and test serum thoroughly on a clean glass plate, and then followed by gentle stirring of the plate for about 4 min using an applicator stick. B. abortus and B. melitensis antigens were used to screen sera samples from cattle and goats respectively. The antigens were procured from the Veterinary Laboratory Agency, Addle stone, Surrey, KT 15-3NB United Kingdom, and preserved at $-20^{\circ} \mathrm{C}$. Sera samples that formed distinct granules (agglutination) within $4 \mathrm{~min}$ of stirring were recorded as positive, containing detectable amount of Brucella antibody; while samples that formed no granules were considered negative, containing no or undetectable amount of the antibody.

\section{Statistical analysis}

Chi-square statistic was used to test for significant association $(\mathrm{p}<0.05)$ between Brucella seropositivity and species, breed, sex, age and season. The statistic was also used to check for significant association $(p<0.05)$ between awareness of brucellosis and demographics and socioeconomic characteristics of the respondents. In addition, statistically significant associations between slaughterhouse practices and educational levels and demographics were also tested for at $\mathrm{p}<0.05$. All the tests were done using IBM ${ }^{\circledR}$ SPSS statistics version 23 (SPSS Inc., Chicago, Illinois) at $5 \%$ probability level.

\section{Results}

Suspected seroprevalence values of $2.5 \%$ and $4.1 \%$ were recorded for Brucella antibody in cattle and goats respectively (Table-1). There was no significant association found at $\mathrm{p}=0.349$ between Brucella seropositivity and the species; although the odds of the disease were about 2 times higher (odds ratio $=1.7,95 \%$ confidence interval: $0.557-5.118$ ) in goats than cattle.

The results on breed, sex, age and seasonal distribution of Brucella antibody in cattle and goats are presented in Tables- 2 and 3 respectively. Brucella antibody was detected mostly in adult and old animals in both cattle (Table-2) and goats (Table-3), but no significant association $(\mathrm{p}<0.05)$ was found between the occurrence of Brucella antibody and breed, age and season in both species. However, sex was strongly associated with Brucella seropositivity in cattle at $\mathrm{p}=0.02$.

The majority $(67.9 \%)$ of the SHWs had not heard of brucellosis (Table-4). The workers were massively involved in practices that could aggravate spread of Brucella infection such as non-use of PPC during slaughterhouse operations (70.8\%), disposal of slaughterhouse wastes, including eviscerated fetuses and pregnant uterine contents, by open-air dump method $(64.9 \%)$ and illegal sale of eviscerated fetuses 
Table-1: Seroprevalence of Brucella antibody in cattle and goats slaughtered in Enugu State, Nigeria.

\begin{tabular}{|c|c|c|c|c|c|c|c|}
\hline Species & Number screened & Number positive & Prevalence & Odds ratio & $95 \% \mathrm{CI}$ & $\chi^{2}$ value & p-value \\
\hline Goats & 340 & 14 & 4.1 & 1.69 & $0.557-5.118$ & 0.877 & 0.349 \\
\hline Cattle & 484 & 12 & 2.5 & & & & \\
\hline Total & 824 & 26 & 3.2 & & & & \\
\hline
\end{tabular}

CI: Confidence interval

Table-2: Breed, sex, age and seasonal distribution of Brucella antibody in cattle $(n=484)$ surveyed in Enugu State, Nigeria.

\begin{tabular}{|c|c|c|c|c|c|}
\hline Variables & Number tested & Number positive & Prevalence & $\chi^{2}$ value & p-value \\
\hline \multicolumn{6}{|l|}{ Breed } \\
\hline White fulani & 286 & 6 & 2.1 & 1.556 & 0.459 \\
\hline Sokoto gudali & 172 & 4 & 2.3 & & \\
\hline Red bororo & 26 & 2 & 7.7 & & \\
\hline \multicolumn{6}{|l|}{ Sex } \\
\hline Cow & 178 & 9 & 5.1 & 7.786 & $0.02 *$ \\
\hline Bull & 306 & 3 & 0.98 & & \\
\hline \multicolumn{6}{|l|}{ Age (years) } \\
\hline Young (1-3) & 76 & 2 & 2.6 & 0.37 & 0.858 \\
\hline Adult (3-8) & 290 & 6 & 2.11 & & \\
\hline Old $(>8)$ & 118 & 4 & 3.4 & & \\
\hline \multicolumn{6}{|l|}{ Season } \\
\hline Wet (Winter) & 168 & 4 & 2.38 & 0.05 & 0.943 \\
\hline Dry (Summer) & 316 & 8 & 2.53 & & \\
\hline
\end{tabular}

*Denotes statistically significant $\mathrm{P}$ value, Chi-square statistic

Table-3: Breed, sex, age and seasonal distribution of Brucella antibody in goats $(n=340)$ surveyed in Enugu State, Nigeria.

\begin{tabular}{|c|c|c|c|c|c|}
\hline Variables & Number tested & Number positive & Prevalence & $\chi^{2}$ value & p-value \\
\hline \multicolumn{6}{|l|}{ Breed } \\
\hline Kano brown & 244 & 8 & 3.3 & 1.574 & 0.455 \\
\hline Sokoto red & 82 & 5 & 6.1 & & \\
\hline Sahel & 14 & 1 & 7.2 & & \\
\hline \multicolumn{6}{|l|}{ Sex } \\
\hline Buck & 58 & 6 & 10.3 & 3.43 & 0.06 \\
\hline Doe & 282 & 8 & 2.8 & & \\
\hline \multicolumn{6}{|l|}{ Age (years) } \\
\hline Young (1-2) & 48 & 2 & 2.3 & 1.06 & 0.59 \\
\hline Adult (2-6) & 196 & 6 & 3.7 & & \\
\hline Old $(>6)$ & 96 & 6 & 3.8 & & \\
\hline \multicolumn{6}{|l|}{ Season } \\
\hline Wet (Winter) & 158 & 6 & 3.8 & 0.38 & 0.85 \\
\hline Dry (Summer) & 182 & 8 & 4.4 & & \\
\hline
\end{tabular}

for human consumption (59.9\%) or preparation of dog food $(71.5 \%)$. There was no significant association $(p>0.05)$ between awareness of brucellosis and gender and age of the SHWs; but statistically significant association was found between educational levels of the respondents and knowledge of brucellosis at $p=0.004$ (Table-5). Similarly, significant associations $(\mathrm{p}<0.05)$ was found between educational levels of SHWs and use of PPC (Table-6) and sell of eviscerated fetuses for human consumption (Table-7).

\section{Discussion}

The suspected seroprevalence of $4.1 \%$ and $2.5 \%$ recorded for Brucella antibody in goats and cattle respectively in this study are lower than the findings of Junaidu et al. [22]; who reported seroprevalence of $20.76 \%$ and $32.2 \%$ respectively for goats and cattle in northern Nigeria. At the international level, particularly in Ethiopia and India, our findings are also lower compared to $9.86 \%$ in goat and $11.74 \%$ in cattle as reported by Negash et al. [28] and Kaushik et al. [29] respectively.

The disparity in the seroprevalence of Brucella antibody found in this and the other studies in various study areas, could be attributed to discrepancies in epidemiological factors capable of influencing the disease dynamics. These factors include livestock husbandry practices, extent of pasture or pastureland contamination with Brucella agents, climatic conditions, source of breeders or replacement stocks, individual differences in interpretation of screening test results and total number of animals sampled.

The herding of different animals species together and practice of extensive husbandry system 
Table-4: Awareness of brucellosis and slaughterhouse practices among slaughterhouse workers $(n=137)$ surveyed in Enugu State, Nigeria.

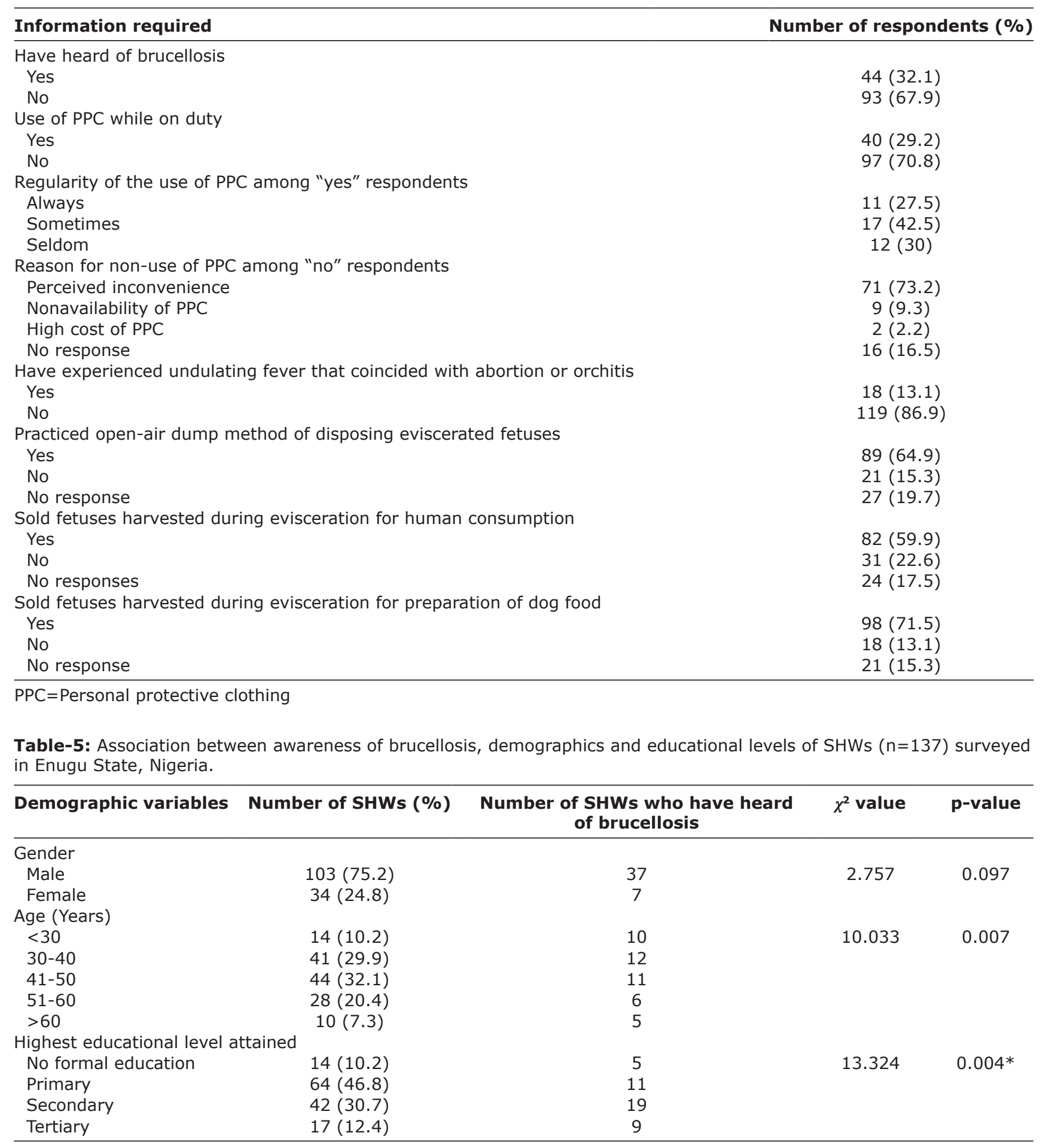

*Denotes statistically significant $\mathrm{P}$ values, SHWs=Slaughterhouse workers

of livestock production are important factors in the epidemiology of dissemination of Brucella infection in animal populations. These practices favor contamination of pasture and pastureland with Brucella agents [19] and facilitate exchange of Brucella species between animals. In Enugu State, cattle and goats are usually not herded together and extensive (free range) husbandry practice is very rare. This may have accounted for the low suspected seroprevalence being reported.
Despite the low seroprevalence found in this work, the threat of brucellosis in the study area still subsists as a single infected animal or individual can easily spread the disease within or across the population. The suspected seroprevalence of $4.1 \%$ in goat found in this study is higher than $1.8 \%$ earlier reported by Onunkwo et al. [30] in the same species and study area. This 128\% increase in Brucella antibody in goats in less than a decade, clearly shows that caprine Brucella infection has continued to rise unabatedly; 
Table-6: Association between slaughterhouse practices and demographics and educational levels of SHWs $(n=137)$ surveyed in Enugu State, Nigeria.

\begin{tabular}{|c|c|c|c|c|c|c|c|}
\hline $\begin{array}{l}\text { Demographic } \\
\text { variables }\end{array}$ & $\begin{array}{c}\text { Number of } \\
\text { respondents (\%) }\end{array}$ & $\begin{array}{l}\text { Number of SHWs } \\
\text { that used PPC }\end{array}$ & $\begin{array}{c}\chi^{2} \\
\text { value }\end{array}$ & p-value & $\begin{array}{l}\text { Number of SHWs that } \\
\text { disposed fetuses by } \\
\text { open-air dump method }\end{array}$ & $\begin{array}{c}\chi^{2} \\
\text { value }\end{array}$ & p-value \\
\hline \multicolumn{8}{|l|}{ Gender } \\
\hline Male & $103(75.2)$ & 33 & \multirow[t]{2}{*}{1.621} & \multirow[t]{2}{*}{0.203} & 69 & \multirow[t]{2}{*}{7.13} & \multirow[t]{2}{*}{0.008} \\
\hline Female & $34(24.8)$ & 7 & & & 20 & & \\
\hline \multicolumn{8}{|l|}{ Age (Years) } \\
\hline$<30$ & $14(10.2)$ & 7 & \multirow[t]{5}{*}{7.782} & \multirow[t]{5}{*}{0.1} & 11 & \multirow[t]{5}{*}{4.81} & \multirow[t]{5}{*}{0.308} \\
\hline $30-40$ & $41(29.9)$ & 13 & & & 22 & & \\
\hline $41-50$ & $44(32.1)$ & 10 & & & 29 & & \\
\hline $51-60$ & $28(20.4)$ & 5 & & & 21 & & \\
\hline$>60$ & $10(7.3)$ & 5 & & & 6 & & \\
\hline \multicolumn{8}{|c|}{ Highest educational level attained } \\
\hline $\begin{array}{l}\text { No formal } \\
\text { education }\end{array}$ & $14(10.2)$ & 5 & \multirow[t]{4}{*}{20.89} & \multirow[t]{4}{*}{$0.000 *$} & 10 & \multirow[t]{4}{*}{10.19} & \multirow[t]{4}{*}{$0.017 *$} \\
\hline Primary & $64(46.8)$ & 8 & & & 49 & & \\
\hline Secondary & $42(30.7)$ & 16 & & & 23 & & \\
\hline Tertiary & $17(12.4)$ & 11 & & & 7 & & \\
\hline
\end{tabular}

*Denotes statistically significant $\mathrm{P}$ values, SHWs=Slaughterhouse workers, PPC=Personal protective clothing

Table-7: Association between the method of disposal of eviscerated fetuses and demographics and educational levels of SHWs $(n=137)$ surveyed in Enugu State, Nigeria.

\begin{tabular}{|c|c|c|c|c|c|c|c|}
\hline $\begin{array}{l}\text { Demographic } \\
\text { factors }\end{array}$ & $\begin{array}{c}\text { Number of } \\
\text { respondents }(\%)\end{array}$ & $\begin{array}{c}\text { Sold fetuses for } \\
\text { human consumption }\end{array}$ & $\begin{array}{c}\chi^{2} \\
\text { value }\end{array}$ & p-value & $\begin{array}{l}\text { Sold fetuses for } \\
\text { preparation of dog food }\end{array}$ & $\begin{array}{c}\chi^{2} \\
\text { value }\end{array}$ & p-value \\
\hline \multicolumn{8}{|l|}{ Gender } \\
\hline Male & $103(75.2)$ & 61 & 0.69 & 0.793 & 67 & 0.069 & 0.079 \\
\hline Female & $34(24.8)$ & 21 & & & 31 & & \\
\hline \multicolumn{8}{|l|}{ Age (Years) } \\
\hline$<30$ & $14(10.2)$ & 8 & 17.40 & $0.002 *$ & 10 & 23.46 & $0.000 *$ \\
\hline $30-40$ & $41(29.9)$ & 21 & & & 31 & & \\
\hline $41-50$ & $44(32.1)$ & 37 & & & 31 & & \\
\hline $51-60$ & $28(20.4)$ & 11 & & & 20 & & \\
\hline$>60$ & $10(7.3)$ & 5 & & & 7 & & \\
\hline \multicolumn{8}{|c|}{ Highest educational level attained } \\
\hline $\begin{array}{l}\text { No formal } \\
\text { education }\end{array}$ & $14(10.2)$ & 13 & 17.63 & $0.001 *$ & 11 & 9.189 & $0.027 *$ \\
\hline Primary & $64(46.8)$ & 44 & & & 47 & & \\
\hline Secondary & $42(30.7)$ & 20 & & & 33 & & \\
\hline Tertiary & $17(12.4)$ & 5 & & & 7 & & \\
\hline
\end{tabular}

*Denotes statistically significant $\mathrm{P}$ values, SHWs=Slaughterhouse workers

and there is an impending danger of brucellosis outbreak and its associated public health and economic consequences in the study area.

Higher seroprevalence of Brucella antibody in goats than cattle may be attributed to the fact that there is no coordinated national brucellosis control programs in goats in Nigeria [24]. Vaccination and other control programs instituted against brucellosis in the past target just the cattle population; not minding the fact that other non-targeted animal species can become reservoirs of the infection for transmission to human and animals or re-infection of even the targeted species. This underscores the need for mass brucellosis vaccination campaign, targeting all susceptible animal species, using Rev. 1 or S19 Brucella strains. This may provide a better result in animal brucellosis control in the country that the current practice that targets only cattle with S19 strain. In addition, the low grazing feeding habit and voracious or "catholic" appetite of goats; unlike cattle, may increase their propensity for Brucella infection, especially when grazing on contaminated pastureland. This further explains the higher Brucella seropositivity found in goats than in cattle in this study.

The preponderance of Brucella antibody in females in both species could be attributed to the affinity which Brucella species have for female reproductive tract and fetal tissues; due to the production of erythritol, a 4-carbon sugar in these tissues that stimulate the growth of Brucella organisms [31]. In addition, female animals are generally kept for longer period in the farm than the males. The extended period of stay of female animals in the farm exposes them to Brucella organisms and hence the chances of acquiring the infection much more than the males. Furthermore, stress associated with pregnancy, parturition and lactation, which female animals usually undergo, tends to lower their immunity and predisposes them to infections with agents like Brucella species.

Although the presence of Brucella antibody in the SHWs was not determined due to uncooperative 
attitude of the workers; reports of undulating fever that coincided with abortion and orchitis in $13 \%$ of the respondents, is strongly evocative of existing Brucella infections. This is most probably in view of the workers involved in certain slaughterhouse practices that predispose to the infection during slaughterhouse operations.

Non-use of PPC by over 70\% of SHWs surveyed suggests that the workers are not just at risk of Brucella infection but represent an important epidemiological link in the transmission of the infection from animals to humans. The animal to human transmission of Brucella infection in Enugu State may be worsened by the fact that most ruminants being slaughtered in the state are sourced from the northern parts of the country, where very high Brucella antibody levels of $37 \%$ in cattle [23] and $30.76 \%$ in goat [22] have been reported. An effective control to this important epidemiological link in transmission of brucellosis from animal to human is provision of free PPC to SHWs for compulsory use during their routine operations and imposition of severe sanctions against defaulters, to tackle the problem of non-use of PPC due to perceived inconveniences.

Improper disposal of slaughterhouse waste, including eviscerated fetuses and other uterine contents by open-air dump method and sale of eviscerated fetuses or pregnant uterine contents for human consumption, as evidenced in this study are potent means of spreading Brucella infection. Open air dump method of disposal of pregnant uterine contents favors the contamination of pasture and pastureland with Brucella species and other infectious agents. This makes acquisition of Brucella infection almost inevitable for animals gracing or scavenging around refuse dumps and carcass processing areas. The sale of fetuses or pregnant uterine content for human consumption in the name of "cheap meat" predisposes buyers to Brucella infection, especially during handling and processing of the meat.

In view of the low infective dose of $B$. melitensis, estimated at $10-100$ colony-forming units $[12,13,31,32]$, their potential for aerosol dissemination [31] and the ability of the organisms to cause protracted and incapacitating disease of enormous public health and economic consequences [12,14]; there is need for a coordinated brucellosis prevention and control programs in the study area to limit the spread of Brucella infection. Such programs must include awareness creation on the mode of acquisition or spread of Brucella infection, as well as the public health and economic consequences associated with the disease. The prevention or control program must, among other things, include mass vaccination campaign, provision of free PPC to occupationally exposed individuals for use during routine operation. The program should also include periodic and serological surveillance studies to monitor the antibody levels in animal and human populations and evaluate the success of the vaccination program respectively. The program should also make provisions for incinerators at the slaughterhouses for proper disposal of eviscerated fetuses and other slaughterhouse or biomedical wastes capable of transmitting Brucella or other infectious agents.

\section{Conclusion}

This study has revealed suspected seroprevalence of $4.1 \%$ and $2.5 \%$ for Brucella antibody in goats and cattle respectively in Enugu State, Nigeria. The 4.1\% seroprevalence in goats represents $128 \%$ increase from $1.8 \%$ seroprevalence recorded by Onunkwo et al. [30] in the same study area. This clearly shows that Brucella infection in goats is on the rise and there is an impending danger of brucellosis outbreak with its associated public health and economic consequences in the study area. SHWs played active roles in spread of Brucella infection as evidenced in non-use of protective clothing during slaughterhouse operations, discharge of eviscerated fetuses or uterine contents by open-air dump method of refuse disposal and sell of fetuses or pregnant uterine contents for human consumption. There is need for coordinated brucellosis prevention or control program, using One Health approach, to tame the tide of rising Brucella infection in Enugu State, for sustainable livestock production and to safeguard human health.

\section{Authors' Contributions}

JIO conceived and designed the study. SOE collected serum samples and screened them for Brucella antibodies. UJN designed the questionnaire and carried out the survey alongside SOE. EON and UJN carried out the statistical analysis. EON drafted and edited the manuscript. All authors read and approved the final manuscript.

\section{Acknowledgments}

The authors acknowledge the staff of Veterinary Public Health and Preventive Medicine Laboratory, University of Nigeria, Nsukka, for their assistance during the Brucella antibody screening. The authors did not receive financial assistance from any source.

\section{Competing Interests}

The authors declare that they have no competing interests.

\section{References}

1. Godfroid, J., Bastuji, B.G. and Saegerman, C. (2013) Brucellosis in terrestrial wildlife. Rev. Sci. Technol., 32: 27-42.

2. Ducrotoy, M., Bertu, W.J., Matope, G., Cadmus, S., Conde-Álvarez, R., Gusi, A.M., Welburn, S., Ocholi, R., Blasco, J.M. and Moriyón I. (2017) Brucellosis in SubSaharan Africa: Current challenges for management, diagnosis and control. Acta Tropica., 165: 179-193.

3. Godfroid, J., Scholz, H.C., Barbier, T., Nicolas, C., Wattiau, P., Fretin, D., Whatmore, A.M., Cloeckaert, A., Blasco, J.M., Moriyón, I., Saegerman, C., Muma, J.B., AlDahouk, S., Neubauer, H. and Letesson, J.J. (2011) Brucellosis at the animal/ecosystem/human interface at the beginning of the $21^{\text {st }}$ century. Prev. Vet. Med., 102: 118-131. 
4. Lindahl, E., Sattorov, N., Boqvist, S., Sattori, I. and Magnusson, U. (2014) Seropositivity and risk factors for Brucella in dairy cows in urban and peri-urban smallscale farming in Tajikistan. Trop. Anim. Health Prod., 46: 563-569.

5. Ogugua, A.J., Akinseye, O.V., Ayoola, M.C., Stack, J. and Cadmus, S.I.B. (2015) Risk factors associated with brucellosis among slaughtered cattle: Epidemiological insight from two metropolitan abattoirs in Southwestern Nigeria. Asian Pac. J Trop. Dis., 5: 747-753.

6. Onunkwo, J.I., Njoga, E.O., Nwanta, J.A., Shoyinka, S.V.O., Onyenwe, I.W. and Eze J.I. (2011) Serological survey of porcine Brucella infection in Southeast, Nigeria. Nigerian Vet. J., 32: 60-62.

7. McDermott, J., Grace, D. and Zinsstag, J. (2013) Economics of brucellosis impact and control in low-income countries. Rev. Sci. et Tech., 32: 249-261.

8. Brisibe, F., Nawathe, D.R. and Bot, C.J. (1996) Sheep and goat brucellosis in Borno and Yobe States of arid Northeastearn Nigeria. Small Rum. Res., 20: 83-88.

9. Bamaiyi, P.H., Khairani-Bejo, S. and Zainal-abidin, M. (2015) The economic impact attributable to brucellosis among goat farms in Peninsula Malaysia and cost benefit analysis. Res Opin. Anim. Vet. Sci., 5: 57-64.

10. Ducrotoy, M.J., Bertu, W.J., Ocholi, R.A., Gusi, A.M., Bryssinckx, W., Welburn, S. and Moriyo'n I. (2014) Brucellosis as an emerging threat in developing economies: Lessons from Nigeria. PLoS Negl. Trop. Dis., 8: e3008.

11. Rossetti, C.A., Arenas-Gamboa, A.M. and Maurizio, E. (2017) Caprine brucellosis: A historically neglected disease with significant impact on public health. PLoS Negl. Trop. Dis., 11: e0005692.

12. Onunkwo, J.I., Njoga, E.O., Njoga, U.J., Ezeokafor, E, Ekere, S.O (2018) Brucella seropositivity in chicken and risk factors for Brucella infection at the animal-human interface in Anambra State, Nigeria. Int. J. One health 4:28-34.

13. Boral, R., Singh, M. and Singh, D.K. (2009) Status and strategies for control of brucellosis - a review. Indian $J$. Anim. Sci., 79: 1191-1199.

14. Njoga, E.O., Onunkwo, J.I., Ekere, S.O., Njoga, U.J. and Okoro, W.N (2018) Seroepidemiology of equine brucellosis and role of horse carcass processors in spread of Brucella infection in Enugu State, Nigeria. Int. J. Curr. Res. Rev., 10:39-45.

15. Rajala, E.L., Grahn, C., Ljung, I., Sattorov, N., Boqvist, S. and Magnusson, U. (2016) Prevalence and risk factors for Brucella seropositivity among sheep and goats in a peri-urban region of Tajikistan. Trop. Anim. Health Prod., 48, 553-558.

16. Adamu, S.G., Atsanda, N.N., Tijjani, A.O., Usur, A.M., Sule, A.G. and Gulani I.A. (2016) Epidemiological study of bovine brucellosis in three senatorial zones of Bauchi State, Nigeria. Vet. World, 9: 48-52.

17. Adamu, N.B., Adeniyi, S.O., Adamu, S.G., Bale, J.O.O., Okoh, A.E.J., Umaru, G.A. and Umar Y.A. (2015) Seroprevalence of brucellosis among livestock workers at Maiduguri cattle market, Borno State, North Eastern, Nigeria. J. Public Health Epidemiol., 7, 253-257.

18. Dean, A.S., Crump, L., Greter, H., Schelling, E. and Zinsstag, J (2012) Global burden of human brucellosis:
A systematic review of disease frequency. PLoS Negl.Trop. Dis., 6: e1865.

19. Cadmus, S.I.B., Ijagbone, I.F., Oputa, H.E. and Adesokan, H.K. (2013) Serological survey of brucellosis in livestock animals and workers in Ibadan, Southwestern, Nigeria. Africa J. Biomed.Res., 9: 163-168.

20. Adesokan, H.K., Alabi, P.I., Stack, J.A. and Cadmus, S.I.B. (2013) Knowledge and practices related to bovine brucellosis transmission amongst livestock workers in Yewa, Southwestern Nigeria. J. South Africa Vet. Asso, 84: 121-125.

21. Kaltungo, B.Y., Saidu, S.N.A., Sackey, A.K.B. and Kazeem, H.M. (2014) A review on diagnostic techniques for brucellosis. African J. Biotech, 13: 1-10.

22. Junaidu, A.U., Oboegbulem, S.I. and Salihu, M.D. (2010) Seroprevalence of brucellosis in prison farms in Sokoto State, Nigeria. Asian J. Epidemiol., 3: 107-111.

23. Mai, H.M., Irons, P.C., Junaidu, K. and Thompson, P.N. (2012) A large seroprevalence survey of brucellosis in cattle herds under diverse production systems in northern Nigeria. BMC Vet. Res., 8: 1-14.

24. Ijale, G.O., Ajogi, I. and Dzikwi, A.A. (2014) Seroprevalence of Brucella antibodies in goats in Oju, Benue State, Nigeria. Asian J. Epidemiol, 6: 43-48.

25. Njoga, E.O., Onunkwo, J.I., Okoli, C.E., Ugwuoke, W.I., Nwanta, J.A. and Chah, K.F. (2018) Assessment of antimicrobial drug administration and antimicrobial residues in food animals in Enugu State, Nigeria. Trop. Anim. Health Prod., 50: 897-902.

26. Pace, J.E. and Wakeman, D.L. (2003) Determining the Age of Cattle by Their Teeth, University of Florida, IFAS Extension. Available from: http://www.edis.ifas.ufl.edu. Retrieved on 6-01-2017.

27. Amin, M.M., Ahmed, S.A., Zaki, H.M. and Ismail, R.I. (2012) Serological and molecular studies on the diagnosis of bovine brucellosis. Nat. Sci., 10: 68-76.

28. Negash, E., Shimelis, S. and Beyene, D. (2012) Seroprevalence of small ruminant brucellosis and its public health awareness in selected sites of Dire Dawa region, Eastern Ethiopia. J. Vet. Med. Anim. Health., 4: 61-66.

29. Kaushik, P., Kumar, M.L., Anjay, S.K. and Kumar P. (2016) Sero-prevalence of bovine brucellosis in Bihar, India. $J$ Vet. Pub. Health, 14: 51-53.

30. Onunkwo, J.I., Nwanta, J.A., Ezenduka, E.V., Oboegbulem, S.I. and Onyenwe, I.W. (2009) Seroepidemiological survey of Brucella infection in slaughterhouse goats in Enugu State of Southeastern Nigeria. Anim. Sci. Reporter., 3: 123-127.

31. Petersen, E., Rajashekara, G., Sanakkayala, N., Eskra, L., Harms, J. and Splitter, G. (2013) Erythritol triggers expression of virulence traits in Brucella melitensis. Microb. Infect, 15: 440-449.

32. Kracalik, I.T., Abdullayev, R., Asadov, K., Ismayilova, R., Baghirova, M., Ustun, N., Shikhiyev, M., Talibzade, A. and Blackburn, J.K (2016) Human brucellosis trends: Re-emergence and prospects for control using a one health approach in Azerbaijan (1983-2009). Zoonoses Public Health, 63: 294-302. 